\title{
Preliminary investigation of the effect of Rhizophora racemosa (mangrove) feed additive on broiler performance
}

\author{
S. N. Wekhe', K. O. Ogbamgba ${ }^{2}$ and C.C. $\mathrm{OBOH}^{1}$ \\ ${ }^{1}$ Department of Animal Science, Rivers State University of Science and Technology, Nkpolu - Port Harcourt, Nigeria. \\ ${ }^{2}$ Rivers Institute of Agricultural Research and Training, Rivers State University of Science and Technology, Nkpolu - \\ Port Harcourt, Nigeria.
}

Accepted 27 April, 2007

\begin{abstract}
An experiment was conducted to determine the effect of consumption of Rhizophora racemosa (Mangrove) incorporated feed on feed intake, body weight gain, and some visceral organs of broiler chicks. Sixty day-old Hubbard broiler chicks were randomly allocated into four treatment groups, A, B, $C$ and $D$ of 15 birds per group and 5 birds per replicate. The dosages of the groups were 0 (control), 10, 20 and $30 \mathrm{~g}$ per kilogram of feed, respectively. Results obtained showed that there were no significant differences $(P>0.05)$ among the treatment means with respect to feed consumption/efficiency, and body weight gain. However, a lineal body weight gain was observed. There was obvious hypertrophy of the bursa of Fabricus of groups B, C, and D, indicative of defensive reaction to $R$. racemosa (foreign body) and increase of antibody production. The observed atrophy of the ovaries and the converse hypertrophy of the testes are analogous to decreased ovarian and increased testicular functions, respectively.
\end{abstract}

Key words: Mangrove, feed intake, weight gain, visceral organs, broilers.

\section{INTRODUCTION}

Rhizophora racemosa is a vast and abundant salt-water forest tree, native to and extending from Senegal in West Africa to Angola in Central Africa. It is also found along the east coast of tropical America and the neighbouring islands. Feed additives are non-nutrients of diverse sources including synthetic, biological, medicinal or mineral sources. They may be anabolic, antibiotics, hormones, plants or shrubs or other chemical agents incorporated in feeds to increase production. For example, the use of antibiotics (Maynard et al., 1979; Griffin, 1979; Taylor, 1988; Wekhe and Taylor, 1992; Wekhe and Olowo, 1994), hormones and anabolic (Phimia, 1987; Berepubo and Wekhe, 1993) and amino acids by Syed et al., 1983; Okonkwo and Alhassan, 1977; Wekhe, 2000) to increase weight gain has been severally reported. The use of the shrub Leucaena leucocephala as a growth promoter in young chicks (D'Mello et al., 1978), the tree Mansonia altissima to increase egg production (Ogbamgba and

\footnotetext{
*Corresponding author. E-mail: yeabuan@yahoo.com.
}

Wekhe, 2005) and $M$. altissima as a growth promoter (Ogbamgba and Wekhe, 2006) have also been reported.

It is the abundance and the seemingly forgotten possibility of the economic use of this abundant foliage, $R$. recemosa, which prompted its trial as an additive in broiler feed. Its implication as a feed additive is that it should be included in very small and insignificant economic quantities capable of impacting desirable or suppressing undesirable properties (Richard, 2001) to add significant economic value. It is the objective of this work to explore the possibility of using the foliage of $R$. racemosa, a mangrove forest tree, as a feed additive to enhance the performance of broilers in the tropics.

\section{MATERIALS AND METHODS}

Sixty (60) day-old Hubard broiler chicks were randomly allocated to four treatment groups A, B, C, and D of 15 birds per group. The groups were further replicated randomly into three sections of 5 birds each. The birds had an initial average weight of $40 \mathrm{~g}$ each at day old. Pen A was the control while B, C, and D were administer- 
Table 1. Rhizophora racemosa (mangrove) feed additive on broiler performance.

\begin{tabular}{|c|c|c|c|c|c|c|c|}
\hline Treatments & $\begin{array}{c}\text { Overall feed } \\
\text { intake } \\
\text { (g/bird) }\end{array}$ & $\begin{array}{c}\text { Daily feed } \\
\text { intake } \\
\text { (g/bird) }\end{array}$ & $\begin{array}{c}\text { Feed to } \\
\text { gain ratio } \\
\text { (g/bird) }\end{array}$ & $\begin{array}{c}\text { Feed } \\
\text { efficiency } \\
\text { (g/bird) }\end{array}$ & $\begin{array}{c}\text { Overall wt. } \\
\text { (g/bird) }\end{array}$ & $\begin{array}{c}\text { Overall wt. } \\
\text { gain (g/bird) }\end{array}$ & $\begin{array}{c}\text { Average } \\
\text { daily wt. gain } \\
\text { (g/bird) }\end{array}$ \\
\hline A & $752.5 \pm 199.7$ & $106.40 \pm 28.38$ & $3.38 \pm 0.48$ & $0.37 \pm 0.09$ & $692.0 \pm 199.4$ & $192.5 \pm 39.8$ & $27.50 \pm 5.69$ \\
B & $804.1 \pm 213.8$ & $114.87 \pm 30.54$ & $3.78 \pm 1.11$ & $0.46 \pm 0.13$ & $844.2 \pm 218.2$ & $207.1 \pm 39.2$ & $29.59 \pm 5.60$ \\
C & $824.2 \pm 211.5$ & $117.74 \pm 30.21$ & $3.17 \pm 0.59$ & $0.50 \pm 0.18$ & $855.5 \pm 216.4$ & $227.1 \pm 39.3$ & $32.45 \pm 5.61$ \\
D & $805.1 \pm 209.7$ & $115.01 \pm 29.96$ & $3.26 \pm 0.65$ & $0.48 \pm 0.16$ & $846.6 \pm 215.0$ & $215.4 \pm 34.2$ & $30.77 \pm 4.89$ \\
\hline TOTAL & $\mathbf{7 9 6 . 5} \pm \mathbf{9 9 . 3}$ & $\mathbf{1 1 3 . 5 1} \pm \mathbf{1 4 . 1 7}$ & $\mathbf{3 . 4 0} \mathbf{0 . 3 6}$ & $\mathbf{0 . 4 5} \pm \mathbf{0 . 0 7}$ & $\mathbf{8 0 9 . 6 \pm 1 0 1 . 7}$ & $\mathbf{2 1 0 . 5} \pm \mathbf{1 8 3}$ & $\mathbf{3 0 . 0 8} \pm \mathbf{2 . 6 1}$ \\
\hline
\end{tabular}

Within column, the means do not differ significantly $(P>0.05)$.

tered the powdered dried mangrove leaf ( $R$. racemosa) on dosages of 10,20 and $30 \mathrm{~g}$ per kilogram of feed respectively. At the end of each week the birds in the replicates were weighed collectively, using Avary Diamond weighing scale. Whole fresh leaves of the mangrove tree $R$. racemosa were harvested at the Eagle Island, Port Harcourt, Nigeria, oven dried at $28-34^{\circ} \mathrm{C}$ for $1-2 \mathrm{~h}$, milled (pulverized), and weighed out according to their treatment levels with the aid of top load balance (Ohaus Scout II). A proximate analysis of the mangrove leave $R$. racemosa was done to determine the crude protein, ash and fat contents. The powder was dispensed (administered) to the birds in their feed from day 1 to day 56 (eighth week), the end of the experiment. The birds were brooded using electric bulb of 200 watts to provide heat. The feed consumption was monitored daily by the difference between the served and the left-over quantities. The data on feed consumption and weight gain of the birds were taken on a weekly basis, and was analyzed by the Analysis of Variance (ANOVA), and the means separated by Duncan Multiple Range Test (DMRT), Gill (1979).

\section{RESULTS}

The proximate composition $(\mathrm{g} / \mathrm{kg})$ of the dried mangrove leaves ( $R$. racemosa) were: crude protein 9.6, ash 34.69, and fat $2.5 \%$. The average weight gain of $1817.1 \mathrm{~g}$ was highest for treatment $C$ which received $20 \mathrm{~g} / \mathrm{kg}$ feed, followed by treatment D $1723.3 \mathrm{~g}$ which received $30 \mathrm{~g} / \mathrm{kg}$ feed, then treatment $B 1656.7 \mathrm{~g}$ which received $10 \mathrm{~g} / \mathrm{kg}$ feed, and lowest for treatment A $1540 \mathrm{~g}$, the control. Birds in treatment $C$ level had the highest weight gain followed closely by those in $\mathrm{D}$ level but there were no significant differences $(P>0.05)$ in their weight gain. Similarly there were no significant differences $(P>0.05)$ in feed consumption among the treatment groups (Table 1).

Post mortem examination of some organs of birds slaughtered showed that the testes of birds in group B $(10 \mathrm{~g} / \mathrm{kg}$ feed) were slightly larger than those of group $\mathrm{C}$ (20 g/ $/ \mathrm{kg}$ feed) and group D (30 g/kg feed). The ovary of group A (control) was slightly bigger (more developed) than those of groups $B, C$, and $D$, while the bursa of Fabricus of group $B(10 \mathrm{~g} / \mathrm{kg}$ feed) was slightly bigger than the other treatment groups. The other visceral organs namely spleen, gizzard, kidney, and heart, did not show any visible differences. A total of 13 birds died during the period of the experiment. Four (4) birds died in treatment group $B$, three (3) in treatment group $C$, and six (6) in treatment group D. Post mortem examination showed that one of the birds in group $\mathrm{C}$ died of coccidiosis.

\section{DISCUSSION}

Observations in this study showed no significant differences $P>0.05$ ) among the treatment groups in their mean final body weights. This means that the additive (powdered $R$. racemosa) did not make any significant impact on the body weight of the birds as was expected. This fact should not condemn the effectiveness of the additive since a marginal (lineal) weight gain was noticed at the end of the experiment that is, a difference of 277.1 $\mathrm{g}$ between birds in treatment $\mathrm{C}$ which received $R$. racemosa at the rate of $20 \mathrm{~g} / \mathrm{kg}$ feed, and birds in the control group A, which received no $R$. racemosa. Also the marginal weight gain could be due to the low level of $R$. racemosa additive used. This implies that higher dosages should be tried. The proximate analysis is convincing that the mangrove foliage, $R$. racemosa, could be utilized as a mineral source for broilers (ash $34.69 \%$ ) and perhaps as forage for lean pork production because of its fat content $(2.5 \%)$ and protein $(9.6 \%)$.

The mortality rate recorded was highest in treatment $D$ (30 g/kg feed), followed by treatment B (10 g/ $/ \mathrm{kg}$ feed), and lowest in treatment $C(20 \mathrm{~g} / \mathrm{kg}$ feed $)$. For the reason of inconsistency in mortality relative to groups, there is no lead to hold $R$. racemosa as causative, more so as one of the deaths in group $C$ was diagnosed as due to coccidiosis. Since the mortality rate was lowest in birds in group $\mathrm{C}$ which recorded the highest weight gain, there is justification in regarding the inclusion level of $R$. racemosa at $20 \mathrm{~g} / \mathrm{kg}$ feed as safe. The death of the bird in group $\mathrm{C}$, at the seventh week of the experiment diagnosed as due to coccidiosis could be the result of failure of the bird to respond to the coccidiostat which was prophylactically administered to the birds in the third week of the experiment.

The testes of birds in treatment $B$ which received the additive at the rate of $10 \mathrm{~g} / \mathrm{kg}$ feed were bigger than those of $C$ and $D$ which received the additive at the rate of $20 \mathrm{~g} / \mathrm{kg}$ feed and $30 \mathrm{~g} / \mathrm{kg}$ feed, respectively. This means that at the inclusion level of $10 \mathrm{~g} / \mathrm{kg}$ feed the effect 
of $R$. racemosa was optimum for the development or sustenance of the testes. This suggests that $R$. racemosa could be used to enhance the performance of breeder cocks in the broiler industry. While this is suggested, there is the need to assay the hormone levels of testosterone at these dosages. Conversely, the ovaries of the control groups were bigger than those of all the other treatment groups. This means that the ovaries were negatively affected while the testes were positively affected by $R$. racemosa. Again, hormonal assay for estrogen is necessary, just like that for testosterone. When this is done using male and female chickens, the effect of $R$. racemosa in laying birds and cocks will be elucidated.

The increase in size of the bursa of Fabricus in groups $B, C$ and $D$, suggests an immunological reaction of the birds to the presence of a foreign body. The bursa of Fabricus is a lymphoepithelial organ peculiar to birds. The hypertrophy of the bursa of Fabricus was due to an increased production of antibody against $R$. racemosa which the body regarded as foreign. This finding corroborates the work of Wekhe (2002) who reported an increase in size of the bursa of Fabricus of broilers fed pulverized root bark of Alchornea cordifolia, and that of Glick et al. (1967) who reported that the bursa of Fabricus conferred immunological competence to fowls. The other visceral organs, namely, liver, spleen, gizzard, kidney, and heart, did not show any visible pathological differences either in size, texture, or appearance. Consequently $R$. racemosa is not toxic to broiler birds at these levels.

\section{Conclusion}

Broiler birds could be fed pulverized leaves of the mangrove tree $R$. racemosa for weight gain though only lineal increases may be observed. The growth enhancing effects of this mangrove tree may be better appreciated if broiler birds are fed fresh leaves or if higher dosages of the pulverized dried leaves are used. It is inconclusive at this point to prescribe $R$. racemosa for weight gain in broilers or to enhance the performance of breeding cocks until further experiments elucidate the enhancing properties more clearly.

\section{ACKNOWLEDGEMENTS}

We are grateful to Mr. Gogo Uranta for field assistance, to Dr. (Mrs.) F. O. Ajayi for biometric analysis and to Miss Beauty Owuru for computer production of this text.

\section{REFERENCES}

Berepubo NA (1993). Influence of Orabolin and Ampicillin on growth rate and oestrus behaviour of female rabbits in the tropics. J. appl. Anim. Sci. Res. 3: 39-45.

D'Mello JPF, Thomas D (1978). The nutritive value of dried Leucaena leucocephala leaf meal from Malawi, studied with young chicks. Tropical Agriculture (Trinidad) 55: 45-50.

Gill VL (1979). Design and Analysis of experiments in Animal and Medical Sciences. $1^{\text {st }}$ edn. Vol.3. Aines, lowa State Univ. Press, lowa, U.S.A.

Glick B (1967). Antibody and gland studies with cortisone and ACTH injected birds. Immunol. 98: 1076-1084.

Griffin RM (1979). Response of caged - reared broiler cockerels to dietary supplements of Nitrovin, Zinc bacitracin, and Penicillin, used singly or in paired combination. J. Brit. Poult. Sci. 20(3): 281-287.

Maynard LA, Loosli JR, Hintz HF, Warner RF (1979). Animal Nutrition, TMII Edn. Ita Mc Graw-Hill Publishing Ltd; New Delhi. p.364-366.

Ogbamgba KO, Wekhe SN (2005). The effect of dietary inclusion of Mansonia altissima on egg production and fertility of laying hens. Afr. J. Biotechnol. 4(10): 1348-1350.

Ogbamgba KO, Wekhe SN (2006). The effect of dietary inclyusion of Mansonia altissima on feed intake, feed effeciency and feed conversion of layig birds and cocks. Afr. J. Biotechnol. 5(10): 10221024.

Okonkwo AC, Alhassan OA (1997). Leucaena leucocephala and Azaridachta indica leaf meals in the diets of laying hens and their effect on egg yolk pigmentation. Nig. J. Anim. Prod. 14: 37-48.

Phimia DB (1987). The effect of feeding orabolin (ethylestrenol) on the growth rate and feed efficiency of broilers in the tropics (Southern Nigeria). Unpublished paper, Department of Animal Science, RSUST, Port Harcourt, Nigeria.

Richard, Wood (2001). Growth promoters of non-antibiotic origin on growth performance of broiler chickens. www.sva.se.

Syed A, Bird HR, Sunde MC, Koegel RG (1983). Effect of added methionine and lysine on the performance of chicks fed different alfalfa protein concentrates. Poult. Sci. Vol. 62( 6): 1021 - 1024.

Taylor BB (1988). Comparing the effects of feeding various levels of ampicillin, terramycin, and cloxacillin on the growth rate of broilers in the tropics. B.Sc. Thesis, Department of Animal Science, RSUST, Port Harcourt, Nigeria.

Wekhe SN, Olowo S (1994). Optimization of growth promoting qualities of ethylestrenol and ampicillin in the broiler industry in the tropics. Discovery and Innovation 6(4): 341-343.

Wekhe SN, Taylor BB (1992). Antifungal-Antibiotic combination as broiler feed additives in the humid tropics. Discovery and Innovation 4: 92-96, 341.

Wekhe SN (2000). The effects of Alchornea cordifolia on the gonads, liver, spleen, pancreas, and bursa of Fabricus of broilers. Proc. $27^{\text {th }}$ Ann. Conf. NSAP, FUT, Akure, March 17-21, 2002, p.86-87. 